\title{
Determination of Microbiological Attributes of Unpackaged and Packaged Raisin Samples Sold in Manisa Markets
}

\author{
Kivilcim Çelik* and Bülent Ergönül \\ Department of Food Engineering, Faculty of Engineering, Manisa Celal Bayar \\ University, Manisa, Turkey \\ *Corresponding Author: Kivilcim Çelik, Department of Food Engineering, \\ Faculty of Engineering, Manisa Celal Bayar University, Manisa, Turkey.
}

Received: March 14, 2020

Published: April 10, 2020

(C) All rights are reserved by Kivilcim Celik and Bulent Ergonul.

\begin{abstract}
Dried raisin which has a high economic value is an essential product of Eagean Region, especially in Manisa. Raisins that can be sold outdoors in some places contain the microbial load. This microbial load may be at levels that may threaten human health. In this study, it is aimed to determine the microbiological attributes of unpackaged or packaged dried raisin samples from different locations of the Manisa region. A total of 62 different dried raisin samples were collected and brought into Manisa Celal Bayar University, Microbiology Laboratory and were taken under microbiological investigation. Average microbiological attributes of 43 unpackaged and 19 packaged dry raisin samples were determined and were compared to values given in Communication for Microbiological Criteria for Dried Fruits and Vegetables of TSE.
\end{abstract}

Keywords: Microbiology; Raisin; Package; Unpackage; E. coli; Staphylococcus aureus

\section{Abbreviation}

Cfu: Colony Forming Units

\section{Introduction}

Grape is a high-calorie food due to its high sugar content. It is also rich in calcium, potassium, sodium and iron. It is also an essential source of vitamins A, B1, B2, B3 and C [1-3]. Grapes have been the subject of research because they contain more phenolic compounds than many fruits and vegetables [4]. Grapefruit is known as effective in the treatment of liver diseases and anemia. It is reported to be good food for the kidney and intestinal system with fruit acids and fibrous structure and it has been reported to play a role in cleaning blood $[1,3]$. As a result of the studies, it was found that grape fruit has high antioxidant substances (tocopherols and phenolic compounds) and dietary fiber content is high. It was found out that grape seed contains high amount of unsaturated fatty acids and approximately 80 - 85\% of these fatty acids are linoleic acid [4]. Furthermore, compounds such as oleanolic acid, oleanolic aldehyde, linoleic acid, linolenic acid, betulin, betulinic acid, 5-(hydroxymethyl)-2-furfural and sitosterol in grapes show antibacterial effect [5].

$35 \%$ of the grapes grown which are produced in Turkey is for drying [6]. Besides, according to 2017 grape production data 1.603 million dried raisins were produced in Turkey [7]. 20 - 28\% of the raisins produced in Turkey are being consumed domestically and the rest is exported. Seedless raisin is the product with the highest export potential with a share of $33.68 \%$ among the product groups in the export of dried fruits and vegetables [8]. Turkey ranks first in market share in world exports of raisins [9].

Drying of food is defined as the removal of moisture from food $[10,11]$. Although the method of drying food base has been applied since the early ages, the transfer of the process to the industrial dimension took place in the 18th century [10]. Drying or dehydration is the process of removing water from solids in order to slow down or stop the growth of microorganisms or chemical reactions. According to another definition, drying is the process by which the water in the fruits and vegetables is reduced to $80-95 \%$ in order to last for a long time [12-15].

Drying applied to foodstuffs has many purposes. The most important of these is to prevent product deterioration during storage. This is achieved by drying the product's moisture to a level sufficient to limit microbial growth and other reactions $[13,16,17]$. Furthermore, by reducing the amount of moisture, the quality properties such as taste, odor and nutritional value are preserved. Another purpose of the drying process is to increase the efficiency of transport and storage by reducing product volume [17,18]. Drying has advantages as well as disadvantages. Color browning, mi- 
crobial load due to drying in open areas and crust formation due to drying are among the disadvantages [15].

The grape drying process is done in 2 different ways. In the open-air drying process, freshly harvested grapes are immersed in the prepared dipping solution and then dried in open-air until a moisture content decrease to 12 - $15 \%$ for about ten days. Naturally, dried grapes are subjected to sulphation after washing. Then the dried grapes are dried in special dryers and then packed according to their size [17,19-21]. Although drying reduces the microbial load in the product, some microbial contamination from environmental factors may occur. If they are examined, usually drying under the sun in the outdoor exhibition area is widespread in Turkey. Consequently, airborne contamination occurs. Bulk sales are made in the unpackaged and therefore contain the microbial load. Since drying is carried out without washing, a microbial load is also generated. As in all products, the microbial load is created if necessary precautions are not taken during storage conditions. Contamination during sales and personnel hygiene is also very important in this regard $[13,16,22]$.

In this study, the comparison of microbial loads of dried raisins and raisin samples sold in packaged in Manisa province in terms of food safety was made. Based on the results obtained from this study, potential risks of raisins were evaluated for human health and process.

\section{Materials and Methods \\ Materials}

In this research, 43 raisin samples sold in unpackaged at different points of sale in Manisa province and 19 raisin samples sold in packaged form were examined. Each sample was placed in locked sterile pouches under aseptic conditions and analyzed on the same day.

\section{Methods}

Total mesophilic aerobic bacteria enumeration (TMAB)

Plate Count Agar (PCA) medium was used for the total number of mesophilic aerobic microorganisms. $1 \mathrm{ml}$ sample taken from the appropriate dilutions (106 dilutions) was added to $15 \mathrm{ml}$ of the medium at $40-45^{\circ} \mathrm{C}$. Petri dishes were incubated at $37^{\circ} \mathrm{C}$ for $24 \mathrm{~h}$. Counts were made according to Plaque Culture Method and results were evaluated as Colony Forming Units (cfu) [23].

\section{Mold and yeast enumeration}

Yeast and mold were defined on Yeast Extract Glucose Chloramphenicol Agar (Merck, 1.16000). Spread plates were incubated at $25^{\circ} \mathrm{C}$ for $3-5$ days.
Sulfite-reducing bacteria were determined in Perfringens Selective Agar (Merck, 1.10235). The roll tube method was used for incubation at $35^{\circ} \mathrm{C}$ for $24 \mathrm{~h}$. Results were evaluated as Colony Forming Units (cfu) [24].

\section{E. coli enumeration}

E. coli 0157: H7 was determined in Sorbitol Mac Conkey Agar (SMAC) (Oxoid, CM0107), pour plates incubated at 37으 $\mathrm{C}$ for $24 \mathrm{~h}$. Results were evaluated as Most Probably Number (MPN) [25].

\section{Staphylococcus aureus enumeration}

S. aureus was defined on Baird-Parker agar (Oxoid CM0275) supplemented with egg yolk-tellurite emulsion (Oxoid SR0054). Spread plates were incubated at $35^{\circ} \mathrm{C}$ for 24 hours. Colonies with typical S. aureus morphology were examined microscopically following Gram staining, and tested for catalase and coagulase activity, and confirmed with DNase Agar (Oxoid CM0321) incubated at $35^{\circ} \mathrm{C}$ for 18 - 24h. Results were evaluated as Colony Forming Units (cfu) [26].

\section{Statistical analyses}

All microbiological analyses were performed in triplicate. The results were presented as mean values.

\section{Results and Discussion}

The average values of the microorganisms detected in packaged raisin samples are given in table 1 as logarithmic $(\log 10 \mathrm{cfu} / \mathrm{g})$. The average values of the microorganisms detected in unpackaged raisin samples are given in table 2 as logarithmic $(\log 10 \mathrm{cfu} / \mathrm{g})$.

In this study, E. coli and mold counts were evaluated according to microbiological values of dried fruits and vegetables in Turkish Food Codex Communiqué on microbiological criteria.

\begin{tabular}{|c|c|c|c|}
\hline TMAB & Mold-Yeast & E. coli & S. aureus \\
\hline $6,1^{*} 10^{2} \mathrm{cfu} / \mathrm{g}$ & $1,1^{*} 10^{1} \mathrm{cfu} / \mathrm{g}$ & $<3 \mathrm{MPN} / \mathrm{g}$ & $<10 \mathrm{cfu} / \mathrm{g}$ \\
\hline
\end{tabular}

Table 1: Average results of microbiological analysis of dried raisins sold in packaged form $(n=19)$.

\begin{tabular}{|c|c|c|c|}
\hline TMAB & Mold-Yeast & E. coli & S. aureus \\
\hline $4,9 \times 10^{3} \mathrm{cfu} / \mathrm{g}$ & $2,8 \times 10^{3} \mathrm{cfu} / \mathrm{g}$ & $<3 \mathrm{MPN} / \mathrm{g}$ & $<10 \mathrm{cfu} / \mathrm{g}$ \\
\hline
\end{tabular}

Table 2: Average results of microbiological analysis of dried raisins which are sold without package $(n=43)$.

\begin{tabular}{|c|c|c|c|c|}
\hline Analyses & n & c & m & M \\
\hline E. coli & 5 & 2 & $<3$ & 9 \\
\hline Mold (cfu/g) & 5 & 2 & $1.0 \times 10^{3}$ & $1.0 \times 10^{4}$ \\
\hline
\end{tabular}

Table 3: Turkish Food Codex Communiqué on microbiological criteria for dried fruits and vegetables. 
Determination of the total number of living, mold and yeasts in foods is widely used in determining the microbiological quality of foods. These analyzes are important in terms of the adequacy of sanitation practices in food establishments and whether they are kept in appropriate conditions during processing, transport and storage of food. These counts generally provide information about the onset of deterioration, the possible shelf life of food, insufficient cooling, contamination and level of production and help to take necessary measures [27].

Determination of the presence of indicator microorganism in food, or presence of this indicator above a certain limit in food, is considered as an indication that food is produced and consumed under conditions that may be contaminated with pathogen or toxin-producing microorganisms. Coliform bacteria are considered as "sanitation indicators". The presence of fecal coliform and E. coli indicates the direct or indirect transmission of human and animal feces. This is also an indication that pathogenic bacteria in the feces can be found in food [27].

When the findings obtained from the study were examined, a total of mesophilic aerobic bacteria was found about 100 times more than those sold in packaged raisins samples. E. coli and $S$. aureus were found below the boundary values for both unpackaged raisins and raisins sold in packages. In the samples sold as packaged, the mold and yeast results were below the limit values, while the products sold in the unpackaged were higher than the limit values according to the Turkish Food Codex Communique on Microbiological Criteria. In light of all these findings, it is seen that the packaged products are more microbiologically safer than the products sold in the unpackaged. Outdoor products threaten public health because they do not have the necessary conditions.

\section{Conclusion}

Grape products and dried raisins are widely consumed products in Turkey. There are different production techniques of raisins. Microbial contamination occurs during outdoor drying. Microbial contamination can occur during contact with air and human during this outdoor sale. In this study, microbiological qualities of raisins sold unpackaged and packaged in Manisa province were determined. As results of the analysis, bacterial counts of $E$. coli and $S$. aureus could not be detected in both samples due to antibacterial compounds such as oleanolic acid. However, the total number of mesophilic aerobic bacteria and mold-yeasts in unpackaged raisins is much higher than the packaged products. According to the Codex Communiqué on Microbiological Criteria, the products sold outdoors are above their limit values. As a result, publicly available products threaten public health because they do not meet the hygiene requirements.

\section{Conflict of Interest}

The authors declare no conflict of interest.

\section{Bibliography}

1. Çelik K. «Determining several quality characteristic of muffin cakes with grape pomace». Manisa Celal Bayar University, Science Institute, Department of Food Engineering (2018).

2. Gülcü M., et al. "Black grapes rich nutrient content and its importance for health". $10^{\text {th }}$ Food Congress of Turkey (2008).

3. Göktaş A. "Grape growing”. Garden Cultures Research Institute in Eğirdir 18 (2008): 1-22.

4. Acun S. "The effect of grape pulp and grape seed with waste from wine enterprises on the quality of biscuits". Süleyman Demirel University, Science Institute, Department of Food Engineering (2011).

5. Farahbakhsh E., et al. "Microbiological quality of raisin dried by different methods". International Journal of Food Safety $\mathrm{Nu}$ trition and Public Health 6.2 (2015): 62-66.

6. Akın A and Altındişli A. "Determination of fatty acid composition and phenolic content of seed oils of emir, gök üzüm and kara dimrit grape varieties". Academic Food Journal 8.6 (2010): 19-23.

7. Ministry of Food, Agriculture and Livestock.

8. TR Prime Ministry Undersecretariat of Foreign Trade Export Incentive Center. Turkey Food Associations Federation (2014).

9. Turantaş F and Sömek Ö. "Determination of mould count, diversity, the effect of storage and dominant mould strains in raisin samples". Food Health 4.2 (2018): 132-139.

10. Baysal T., et al. "Packaging and storage of dried products". $11^{\text {th }}$ National Installation Engineering Congress (2013): 37-41.

11. Al Askari G., et al. "Physicochemical and microbiological study of "Raisin", local and imported (Morocco)". Middle-East Journal of Scientific Research 11.1 (2012): 1-6.

12. Erdem T., et al. "Color change analysis of dried orange slices during hot air color change analysis of dried orange slices". Fresenius Enviromental Bulletin 27.9 (2018): 6064-6072.

13. Perera CO. "Selected quality attributes of dried foods". Drying Technolgy 23.4 (2005): 717-730.

14. Ratti C. Advances in Food Dehydration. Ratti C, editor. CRC Press Taylor\&Francis Group (2009): 488.

15. Mahayothee B., et al. "Influence of drying conditions on colour, betacyanin content and antioxidant capacities in dried redfleshed dragon fruit (Hylocereus polyrhizus)". International Journal of Food Science and Technology 54.2 (2019): 460-470. 
16. İçier F and Sabancı S."Htgiene in Drying and Operation". $11^{\text {th }}$ National Installation Engineering Congress (2013): 29-36.

17. Khiari R., et al. "Raisin processing: physicochemical, nutritional and microbiological quality characteristics as affected by drying process". Food Reviews International 35.3 (2019): 246-298.

18. Morata A., et al. "Grape drying: current status and future trends". Grape and Wine Biotechnology (2016): 145-165.

19. Rustioni L., et al. "Optical properties of berry epicuticular waxes in four Georgian grape cultivars (Vitis vinifera L.)". South African Journal of Enology and Viticulture 33.2 (2012): 138-143.

20. Adiletta G., et al. "Drying characteristics and quality of grape under physical pretreatment". Journal of Food Engineering 172 (2016): 9-18.

21. Lydakis D., et al. "Optimization study of sulfur dioxide application in processing of sultana raisins". International Journal of Food Properties 6.3 (2003): 393-403.

22. Akbal N and Vural A. "Investigation of microbiological quality properties of dried fruit samples". Dicle University Journal of Veterinary Medicine (2018): 93-97.

23. BAM (Bacteriological Analytical Manual). "Chapter 3: Aerobic Plate Count" (2020).

24. BAM (Bacteriological Analytical Manual). Chapter 18: Yeasts, Molds and Mycotoxin (2020).

25. BAM (Bacteriological Analytical Manual). Enumeration of Escherichia coli and the Coliform Bacteria (2020).

26. BAM (Bacteriological Analytical Manual). Enumaration of Staphylococcus aureus. (2020).

27. Vural A and Yeșilmen S. "A research on microbiological quality of raw meatballs for sale in Diyarbakır". Turkish Journal of Microbiology Society 33 (2003): 350-355.

\section{Assets from publication with us}

- Prompt Acknowledgement after receiving the article

- Thorough Double blinded peer review

- Rapid Publication

- Issue of Publication Certificate

- High visibility of your Published work

Website: https://www.actascientific.com/

Submit Article: https://www.actascientific.com/submission.php Email us: editor@actascientific.com

Contact us: +919182824667 